\title{
Determinants of young people's sexual behaviour concerning HIV and AIDS in the practice population of a university health centre in Lagos, Nigeria
}

\author{
Authors: \\ Olayinka O. Ayankogbe ${ }^{1}$ \\ Kofo Odusote 2 \\ Mopelola O. Omoegun ${ }^{3}$ \\ Victoria Ofoha ${ }^{2}$ \\ Ayoade Adedokun ${ }^{4}$ \\ Kehinde O. Abiola ${ }^{5}$

\section{Affiliations: \\ ${ }^{1}$ Department of Community Health and Primary Care, College of Medicine, University of Lagos, Nigeria \\ ${ }^{2}$ Health Center, University of Lagos, Nigeria \\ ${ }^{3}$ Department of Guidance and Counseling, Faculty of Education, University of Lagos, Nigeria \\ ${ }^{4}$ Department of Family University Teaching Hospital, Ikeja, Nigeria} \\ Medicine, Lagos State
}

\section{${ }^{5}$ Department of Laboratory} Services, Health Centre, University of Lagos, Nigeria

\section{Correspondence to:}

Olayinka Ayankogbe

Email:

yinayanks@yahoo.com

Postal address:

P.M.B. 12003, Lagos, Nigeria

\section{Dates:}

Received: 12 Aug. 2010 Accepted: 29 Nov. 2010 Published: 10 June 2011

How to cite this article: Ayankogbe OO, Odusote $\mathrm{K}$, Omoegun $\mathrm{MO}$, Ofoha V, Adedokun A, Abiola KO. Determinants of young people's sexual behaviour concerning HIV and AIDS in the practice population of a university health centre in Lagos, Nigeria. Afr J Prm Health Care Fam Med. 2011;3(1), Art. \#219, 8 pages. doi:10.4102/phcfm.v3i1.219
Background: AIDS has been a scourge of universities in Africa for a long time. This study was launched at ground-level to fight the dreaded disease by concentrating on young people and to counter the ignorance that surrounds the disease even in numerous African universities. This study of the student community was carried out by family doctors at the University Health Department to determine the prevalence of the determinants of young people's reproductive health behaviour.

Objectives: This study is aimed at determining young people's sexual behaviour concerning HIV and AIDS in the practice population of a university in Lagos, Nigeria.

Method: Self-administered 63-item questionnaires were distributed amongst 2000 randomly selected students of the University of Lagos, Lagos, Nigeria in September 2005, using a semistructured form of the Comprehensive Youth Survey questionnaire, developed by FOCUS (led by Pathfinder International, Futures Group International and Tulane University School of Public Health).

Results: The age distribution of the respondents was designated in the age groups of 15-19 years $(15.8 \%), 20-24$ years $(60.1 \%), 25-29$ years $(19.6 \%), 30-34$ years $(2.8 \%)$. Demographics of note were that $88.3 \%$ of the fathers of the respondents were literate and that $94.5 \%$ of the fathers earned more than one US \$ per day. The majority of the respondents $(99.1 \%)$ indicated adherence to one religious faith or the other and $58.8 \%$ believed definitely that religion shaped their attitudes about sexual intercourse and sexuality. More than half (64.0\%) denied having had sex at all in the three months preceding the study. Furthermore, $68.8 \%$ affirmed that it was common amongst friends of their age to use condoms. A significant number of respondents $(65.5 \%)$ thought that their friends have drunken alcohol. Almost all of the respondents $(94.3 \%)$ had a positive perception of their family.

Conclusion: The Programming for HIV and AIDS Reduction on university campuses in Africa should be conducted comprehensively rather than monothematically and should, take into consideration the five thematic areas of behaviour change communication amongst young people concerning their reproductive health.

\section{Introduction}

AIDS remains a dreaded disease ${ }^{1}$ in Africa, and every effort should be made to prevent it especially in young people who are disproportionately affected. ${ }^{2,3,4,5,6}$ In his seminal report on case studies of seven Universities in Africa on HIV and AIDS in 2001, Kelly ${ }^{7}$ concluded that a thick coat of ignorance surrounds the disease in many African universities. This cloak is amply lined with layers of secrecy, silence, denial and fear of stigmatization and discrimination. ${ }^{7}$ Records that name the disease available in University Health Centres are just being upgraded. ${ }^{7}$ Even information on staff and student mortality is just being improved. ${ }^{7}$ However, sexual activity, especially amongst the students, is rampant in all these universities, both in Africa and all over the world. ${ }^{8,9,10}$

Several studies on sexual related behaviour of students in the universities also corroborate the extent of high risk behaviour for HIV and AIDS present in these citadels of higher learning, whether in developed or developing countries. . $11,12,13,14,15,16^{-16}$

Extensive research into adolescent and young people's behaviour concerning reproductive health has identified five thematic areas that influence these behaviours. ${ }^{4,17,18,19,20}$ These areas 
comprise firstly, the individual characteristics of young people, including their knowledge, attitudes, beliefs, values, motivations and experiences. Secondly, their sexual partners and peers and thirdly, their families and the adults in the community play a role. Fourthly, institutions that support the youth and provide opportunities, such as schools, workplaces and religious organisations influence young people's behaviour. Finally communities, through which social expectations are transmitted about gender norms, sexual behaviour, marriage and child bearing, is an important thematic area. ${ }^{17,18,19}$

There were no definite figures of reproductive health problems, ${ }^{7}$ but, observations showed that these could be substantial, as the Centre was dealing with a very large student population. Using some of the processes of Community Orientated Primary Care, ${ }^{21,22}$ a study was conceived to investigate the problems that prevail concerning reproductive health behaviour in the population of the general or family practice.

Behaviour Change Communication regarding HIV and AIDS has been ongoing in the community surrounding the University of Lagos from the first report of HIV or AIDS in Nigeria in 1981. In 2005, activities specifically targeted at the Lagos University students gained momentum. Although undocumented scientifically, these activities included peer education, dissemination of Information Education Communication (IEC) materials, the formation of a student's anti-AIDS club and the preparation of a draft policy document for HIV and AIDS for students and workers on campus. With the award of an intervention grant by PEPFAR (United States Presidential Emergency Programme Fund for Aids Reduction) in September 2005, a baseline study of the student community was carried out by family doctors (family physicians and medical officers). This study was undertaken at the health centre in collaboration with a multidisciplinary team of sociologists, graduate nurses and public health physicians, to determine the prevalence of the determinants of young people's reproductive health behaviour in this practice population of the University Health Centre.

\section{Ethical considerations}

Ethical considerations was obtained from the Lagos University Teaching Hospital Research and Ethics Committee. Written informed consent was obtained from each of the participants.

\section{Method}

The University of Lagos Health Centre is a general practice facility run by generalist doctors and medical officers with Master degrees in Public Health. In 2006, the facility attended to a total of 33857 patients comprising 5618 student patients (out of a total of 30000 students), 8027 staff patients and 20192 dependent patients (i.e. the spouses and children of students and staff).

Self-administered 63-item questionnaires were distributed amongst 2000 randomly selected students from the University of Lagos in Lagos, Nigeria. The university has a total student population of 30000 (both in campus and off campus). The standard Comprehensive Youth Survey questionnaire, developed by FOCUS (a partnership of Pathfinder International with the Futures Group International and Tulane University School of Public Health), was used. This instrument is an internationally validated instrument used in surveys of reproductive health behaviour in young people all over the world. It covers the five thematic areas of youth behaviour concerning reproductive health. These questionnaires were distributed during official school sessions. A 3-stage multistage sampling design was used to select 200 respondents from each of the 10 faculties of the university including the College of Medicine. In the first stage all the faculties were selected. In the second stage all the departments in each faculty were selected and the 200 respondents from each faculty were distributed according to the number of departments in that particular faculty. Simple random samples were then taken by balloting to select the final number of students from each department. The minimum sample size of 1536, (rounded up to 2000) was arrived at by using the formula:

$$
\begin{aligned}
& (1.96)^{2}(p)(1-p) / d^{2} \\
& \text { where } p \text { is the prevalent rate }(0.5) \text { and } \\
& d \text { is the margin of acceptable error }(2.5 \%) \text {. }
\end{aligned}
$$

Postgraduate student volunteers, trained in data collection through a one-day workshop, distributed the questionnaires. A pilot survey was conducted using a nearby tertiary institution to restructure the survey questionnaire to meet local needs. Data from the questionnaires were fed into the computer and analysed using the software EPIINFO version $6.04 \mathrm{~b}$. All bona fide students of the university were expected to participate in the study whether they stayed on campus or off campus.

A total of 1891 questionnaires were retrieved, equalling a response rate of $94.6 \%$.

\section{Results}

The Age Distribution (Table 1) shows that the age group of 1524 years constituted $60.1 \%$ of the study group. The majority $(91.1 \%)$ were not married, as can be expected from their ages and $88.3 \%$ of the fathers were literate (i.e. they have had more than 11 years of continuous education).

In general, respondents had a more than average knowledge about HIV and AIDS and the prevention of it and were aware of where to find help in a majority of cases (Table 3 ).

\section{Religion}

A significant percentage (58.8\%) has a firm conviction that religion shapes their attitudes about sexual intercourse and sexuality whilst $24.6 \%$ have a firm belief that it does and $5.4 \%$ accept that it does.

The pertinent religious debate about AIDS and sin in relation to this study reveals that $90.5 \%$ of the respondents do not believe that people who contracted HIV or AIDS are sinners. 
TABLE 1: The demographic profile of the respondents with reference to their age, gender, relationship status and their home background.

\begin{tabular}{|c|c|c|}
\hline Profile & Frequency & $\%$ \\
\hline \multicolumn{3}{|l|}{ Age group (years) } \\
\hline $15-19$ & 299 & 15.8 \\
\hline $20-24$ & 1137 & 60.1 \\
\hline $25-29$ & 370 & 19.6 \\
\hline $30-34$ & 53 & 2.8 \\
\hline $35-39$ & 17 & 0.9 \\
\hline 40 and above & 15 & 0.8 \\
\hline \multicolumn{3}{|l|}{ Gender $^{\mathrm{a}}$} \\
\hline Male & 694 & 36.7 \\
\hline Female & 1197 & 63.3 \\
\hline \multicolumn{3}{|l|}{ Relationship status } \\
\hline Single & 1724 & 91.1 \\
\hline Married & 134 & 7.1 \\
\hline Divorced & 4 & 0.2 \\
\hline Separated & 4 & 0.2 \\
\hline Live-in lover & 25 & 1.3 \\
\hline \multicolumn{3}{|l|}{ Religious denomination } \\
\hline None & 19 & 1 \\
\hline Roman Catholic & 327 & 17.3 \\
\hline Protestant (Anglican, Methodist, etc.) & 96 & 5 \\
\hline Protestant (Pentecostal) & 777 & 41.1 \\
\hline Moslem & 327 & 17.3 \\
\hline Indigenous (white garment) & 97 & 5.1 \\
\hline Others & 248 & 13.1 \\
\hline \multicolumn{3}{|l|}{ Father's level of education } \\
\hline None & 81 & 4.3 \\
\hline Primary school & 108 & 5.7 \\
\hline Secondary school uncompleted (=JSS3) & 32 & 1.7 \\
\hline Secondary school completed (>JSS3) & 159 & 8.4 \\
\hline Post-secondary & 255 & 13.5 \\
\hline University or polytechnic & 1256 & 66.4 \\
\hline Total & 1891 & 100 \\
\hline
\end{tabular}

Source: Authors' original data

a, $63.3 \%$ were female students whilst $36.7 \%$ were male students, giving a female to male student ratio of $1.7 / 1$.

TABLE 2: The social class and income of the respondents' fathers.

\begin{tabular}{|c|c|c|}
\hline Description & Frequency & $\%$ \\
\hline \multicolumn{3}{|l|}{ Father's social class ${ }^{\mathrm{a}}$} \\
\hline $\begin{array}{l}\text { I: Professional occupations } \\
\text { (doctors, etc.) }\end{array}$ & 879 & 46.5 \\
\hline $\begin{array}{l}\text { II: White collar workers } \\
\text { (shop owner, etc.) }\end{array}$ & 197 & 10.4 \\
\hline $\begin{array}{l}\text { III: Formally trained occupation } \\
\text { (police etc.) }\end{array}$ & 76 & 4 \\
\hline $\begin{array}{l}\text { IV: Trained occupations with overalls } \\
\text { (welders, etc.) }\end{array}$ & 38 & 2 \\
\hline $\begin{array}{l}\text { V: Untrained occupations - no overalls } \\
\text { (guards) }\end{array}$ & 13 & 0.7 \\
\hline $\begin{array}{l}\text { VI: Untrained occupation - overalls } \\
\text { (gardeners etc.) }\end{array}$ & 15 & 0.8 \\
\hline Other (unclassifiable) & 673 & 35.6 \\
\hline \multicolumn{3}{|c|}{ The average income of the father in naira per month $(1 \mathrm{USD}=\mathrm{N} 100)^{\mathrm{b}}$} \\
\hline Less than 2000 & 59 & 3.1 \\
\hline 2000-3999 & 40 & 2.1 \\
\hline 4000-5999 & 79 & 4.2 \\
\hline $6000-7999$ & 76 & 4 \\
\hline 8000 and above & 1.638 & 86.6 \\
\hline Total & 1891 & 100 \\
\hline
\end{tabular}

Source: Tropical doctor; Authors' original data

USD, American dollar; N, naira.

a, Social classes are classified according to a Roman numeral numbering system.

, Note that $94.5 \%$ of the students' fathers earn more than 1 US $\$$ per day.
TABLE 3: Personal HIV related knowledge and attitude.

\begin{tabular}{lll}
\hline Description & Frequency & $\%$ \\
\hline Involvement with extra- curricular activities on campus (respondents chose more \\
than one option) & & \\
Yes & - & 40.7 \\
No & - & 59.3 \\
If yes & 232 & - \\
Sport clubs or club teams & 77 & - \\
Drama clubs & 23 & - \\
Debate clubs & 107 & - \\
Academic clubs & 516 & - \\
Religious clubs & 54 & - \\
Other & 789 & - \\
Meaning of safe sex (respondents chose more than one option) & \\
Abstaining from sex & 876 & - \\
Using condoms & 571 & - \\
Avoiding multiple sexual partners & 337 & - \\
Avoiding sex with prostitutes & 244 & - \\
Avoiding anal sex & 25 & - \\
Others & 1891 & - \\
Preferred facility for reproductive health problems (respondents chose more than \\
one option) & & - \\
Clinic or hospital & 1475 & - \\
Chemist & 36 & - \\
Health worker & 97 & - \\
Peer counsellor & 38 & - \\
Youth Centre & 23 & - \\
Friend & 63 & - \\
Parent & 149 & - \\
Relative & 14 & - \\
Lecturer & 20 & - \\
Other & 50 & - \\
Total & 100 & \\
\hline Source:Auths' & & - \\
\hline
\end{tabular}

Source: Authors' original data

TABLE 4: Knowledge and attitudes that respondents revealed on how to safeguard themselves against AIDS.

\begin{tabular}{lll}
\hline Variable & Frequency & $\%$ \\
\hline What can a person do to avoid AIDS (respondents chose more than one option)? \\
Avoid sex completely & 1128 & - \\
Stay faithful to a partner & 1136 & - \\
Encourage partner to stay faithful & 958 & - \\
Use condom for every act of sexual intercourse & 776 & - \\
Avoid sharing needle & 954 & - \\
Avoid commercial sex workers & 821 & - \\
Avoid casual sex & 838 & - \\
Avoid circumcision in unauthorized places & 830 & - \\
Other (to enumerate in footnotes if possible) & - & - \\
\hline Total & $\mathbf{1 8 9 1}$ & $\mathbf{1 0 0}$ \\
\hline
\end{tabular}

Source: Authors' original data

\section{Behavioural practices}

When asked how many times they had sexual intercourse in the three months preceding the study, 64\% denied having had sex at all. Of the rest, $6.4 \%$ admitted to have had sex once, and $6.7 \%$ admitted to two to three times. Furthermore, 3.1\% admitted to four to five times, $3.2 \%$ to six to eight times and $5.4 \%$ to nine or more times, whilst $11.1 \%$ said that they could not remember. That means that $24.8 \%$ admitted to have had sexual intercourse in the three months preceding the study.

In the evaluation of the number of partners they have had sex with in the three months preceding the study, $63.1 \%$ said 
none, $25.2 \%$ said one, $5 \%$ said two, $2.4 \%$ said three whilst the rest had partners varying from four to eight $(2.1 \%)$. Consequently a total of $9.5 \%$ admitted to having had multiple sexual partners.

The social aspect of coerced sexual intercourse revealed that $20 \%$ of the students had been forced to have sexual intercourse, whilst 78\% had not been forced (Table 5). The results also showed that $87.6 \%$ of the students had never received anything in exchange for sex whilst $9.1 \%$ had and $26.2 \%$ are currently in a same sex relationship.

\section{Condom use}

During the study $68.8 \%$ of the respondents affirmed that amongst friends of their age, it was common to use condoms and $47.2 \%$ of the students admitted to using condoms.

In the two major areas of assessment of self-efficacy amongst these respondents, the scores were very high (Table 5).

\section{Mass media influences}

The influence of the mass media, such as radio and television, can be seen globally. In this study, the record of the frequency with which students listen to the radio revealed that $65.8 \%$ of the students listened to the radio every day or almost every day, $21.8 \%$ listened to it at least once per week and 3.8\% listened at least once per month. Very few did not listen to the radio regularly; $2.9 \%$ listened to it less than once per month and a very low percentage of $2.5 \%$ of the students never listened to the radio.

When asked how many times they had listened to Radio Unilag, in the preceding two weeks to the study, only 39\% said zero number of times. The rest has listened to it in varying numbers of times ranging from once to 60 times.

The most significant data on peer and partner pressure (Table 6) are that $57.9 \%$ did not agree that they should put pressure on their partner to have sex with them; unfortunately, less, but still a significant portion, that is, $48.6 \%$ affirmed that unmarried female students in the university community encourage other girls to have sex with male students or older men. At the same time, $49.6 \%$ affirmed that unmarried male students in the university community encourage other male students to have sex with female students or older women. It is encouraging that $60.5 \%$ said that there was no pressure from their friends for them to have sexual intercourse.

When the respondents were asked if a peer educator has ever talked to them, $54.6 \%$ replied in the affirmative. Of those who have talked to a peer educator, $63.7 \%$ would like to talk to one again and $16.4 \%$ were undecided.

A significant number of the respondents, $65.5 \%$ of the study group, thought that their friends have drunk alcohol and only $19.3 \%$ of the respondents thought that none of their friends have drunk alcohol (Table 7). It is encouraging that there was a strong perception amongst the respondents that their friends did not use drugs, that is, $78.4 \%$ of the respondents. Smoking seemed to be more common, as $56.9 \%$ agreed that their friends have smoked.

\section{Family influence}

Approximately half (52.2\%) of the students described their family to be sweet and warm in general. A majority of the respondents $(79.8 \%)$ said that their parents supported their decisions and $61.9 \%$ of this majority said that their parents mostly supported them whilst $17.9 \%$ said that they were fully supportive (Table 8). A smaller percentage (10.5\%) revealed that they did not know whether their parents supported their decisions.

Most of the students (78.1\%) had a good relationship with their brothers and sisters, and $45.3 \%$ of those students had a good relationship with their brothers and sisters all the time, whilst $32.8 \%$ usually related to one another. The rest of them, that is, $17.1 \%$, sometimes related to one another (Table 8 ).

\section{Discussion}

This study set out to explore the distribution of known determinants that influence behaviour change amongst the

TABLE 5: An assessment of the self-efficacy of the respondents.

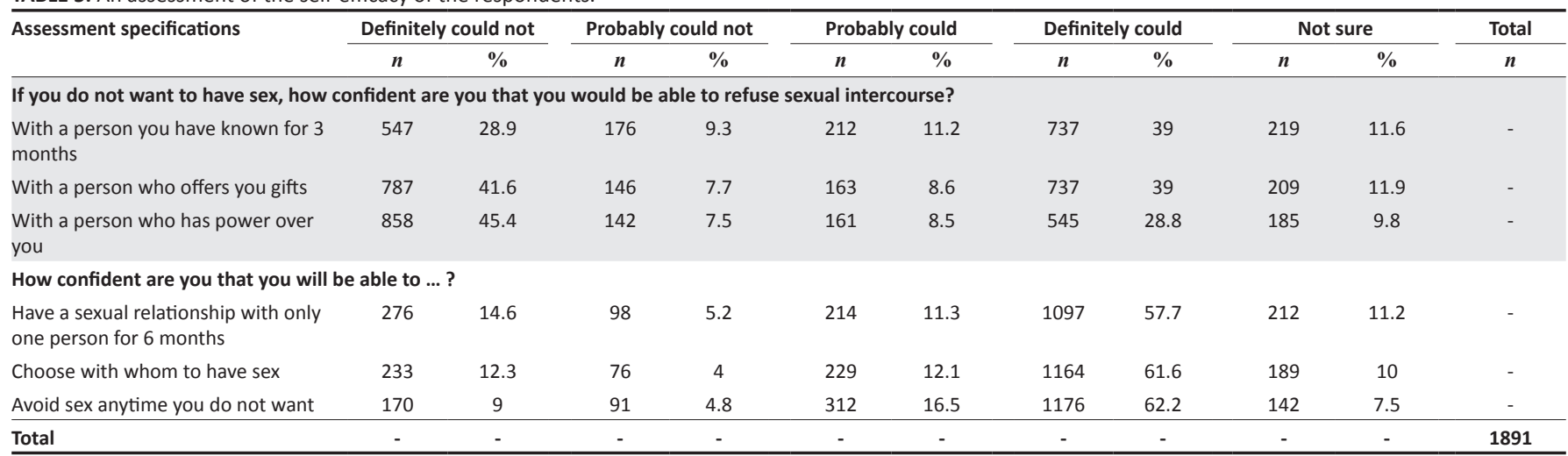

Source: Authors' original data 
TABLE 6: Peer and partner pressure.

\begin{tabular}{|c|c|c|}
\hline Variable & $n$ & $\%$ \\
\hline \multicolumn{3}{|c|}{ Putting pressure on partner to have sex. } \\
\hline Agree & 465 & 24.6 \\
\hline Disagree & 1097 & 58 \\
\hline Do not know & 329 & 17.4 \\
\hline \multicolumn{3}{|c|}{$\begin{array}{l}\text { Unmarried female students encouraging other girls to have sex with male students } \\
\text { or older men. }\end{array}$} \\
\hline Yes & 919 & 48.6 \\
\hline No & 327 & 17.3 \\
\hline Do not know & 645 & 34.1 \\
\hline \multicolumn{3}{|c|}{$\begin{array}{l}\text { Unmarried male students encouraging other male students to have sex with female } \\
\text { students or older women. }\end{array}$} \\
\hline Yes & 938 & 49.6 \\
\hline No & 302 & 16 \\
\hline Do not know & 651 & 34.4 \\
\hline \multicolumn{3}{|c|}{ Have you ever been encouraged? } \\
\hline Yes & 520 & 27.5 \\
\hline No & 1237 & 65.4 \\
\hline Do not know & 134 & 7.1 \\
\hline \multicolumn{3}{|c|}{ Support amongst friends to wait until marriage before having sexual intercourse. } \\
\hline No support at all & 397 & 21 \\
\hline A little support & 499 & 26.4 \\
\hline Moderate support & 341 & 18 \\
\hline Substantial support & 654 & 34.6 \\
\hline \multicolumn{3}{|c|}{ Pressure from friends to have sexual intercourse. } \\
\hline No pressure at all & 1145 & 60.5 \\
\hline A little pressure & 422 & 22.3 \\
\hline Moderate pressure & 125 & 6.6 \\
\hline Substantial pressure & 199 & 10.6 \\
\hline Total & 1891 & 100 \\
\hline
\end{tabular}

Source: Authors' original data

Number of respondents is given as $n$.

youth concerning HIV and AIDS. The five thematic areas that influence behaviour change are strong in this West African citadel of learning. These thematic areas were not explored in this particular study, but the implications are enormous for the control of HIV and AIDS on campuses not only in Nigeria, but across the continent.

\section{Demographics}

The socioeconomic milieu that puts people at risk of HIV and AIDS is absent in this student population. With the majority of the students in Social Classes $\mathrm{I}$ and $\mathrm{II}^{23}$ as classified in Table 2, and income brackets of N8000 per month and above, they are not in the poverty trap, nor are they in the low socioeconomic group that is associated with high HIV and AIDS prevalence. Students in a higher educational institution have a tremendous advantage, for' higher education students are more likely to have sexual education ${ }^{25,26}$. Furthermore, condom use in particular has been found to increase in student populations with higher levels of education. ${ }^{27}$

\section{Personal HIV related knowledge and attitudes}

Personal HIV related knowledge is as high in this student population as in other university student populations in Africa ${ }^{26}$; this can also be said about most universities in Nigeria. However, unlike most other studies where permissive attitudes prevail, attitude levels towards sexual activity are low..$^{20,28,30}$ This suggests that behaviour change communication strategies finally seem to be working in this student community in Lagos judging from the fact that peer education, behaviour change communication and HIV mitigating policy processes were on-going prior to the study.

The perception of risk of HIV infection is low. This is the general trend amongst Nigerians of all ages and may be attributed to the fact that Nigeria has a low prevalence rate of $4.8 \%{ }^{54}$ This low rate of perception of risk follows findings in the developed world too. ${ }^{28,29}$ It is universally low amongst young people, who are eternal optimists. This underscores the fact that preventive efforts concerning HIV and AIDS must become a lifestyle.

\section{Religion}

In this series, religious influence was significant in influencing attitudes to sex and consequently preventative behaviour towards HIV and AIDS. Although not deeply explored in this student population, high levels of religiosity are associated with low levels of sexual activity. Few studies are available to compare with those in Nigeria. Nevertheless, religion plays a major role in the consciousness of Nigerians. Many HIV and AIDS prevention activities are now handled successfully by faith-based organisations, a testimony to this trend. This trend is also found in the rest of Africa. ${ }^{20,27}$ This seems to be unique to Africa and in particular to Nigeria. ${ }^{25}$

\section{Behavioural practices}

Rates of sexual activity amongst students in this series are consistently low at $24.8 \%$, although when compared to secondary school students in Malaysia, another developing country, the rates of sexual activity in this study are higher $\left(12.6 \%\right.$ in Malaysia). ${ }^{31}$ Much higher rates are found in developed countries. ${ }^{33,34,35}$ The incidence of multiple sexual partners is low as well. The only explanation is that the five

TABLE 7: The use of substances and the perception of the use of substances by friends of the respondents.

\begin{tabular}{|c|c|c|c|c|c|c|c|c|c|c|c|c|c|}
\hline \multirow[t]{2}{*}{ Substance } & \multicolumn{2}{|c|}{ None of them } & \multicolumn{2}{|c|}{ A few of them } & \multicolumn{2}{|c|}{$\begin{array}{l}\text { About half of } \\
\text { them }\end{array}$} & \multicolumn{2}{|c|}{ Most of them } & \multicolumn{2}{|c|}{ All of them } & \multicolumn{2}{|c|}{ Do not know } & \multirow{2}{*}{$\begin{array}{c}\text { Total } \\
n \\
\end{array}$} \\
\hline & $n$ & $\%$ & $n$ & $\%$ & $n$ & $\%$ & $n$ & $\%$ & $n$ & $\%$ & $n$ & $\%$ & \\
\hline $\begin{array}{l}\text { Number of friends that have drank } \\
\text { alcohol. }\end{array}$ & 365 & 19.3 & 785 & 41.5 & 91 & 4.8 & 272 & 14.4 & 85 & 4.5 & 293 & 15.5 & - \\
\hline Friends that have taken drugs & 1483 & 78.4 & 280 & 14.8 & 15 & 8 & 59 & 3.1 & 40 & 2.1 & 15 & 8 & - \\
\hline Number of friends who have smoked & 756 & 40 & 921 & 48.7 & 74 & 3.9 & 108 & 5.7 & 28 & 1.5 & 4 & 0.2 & - \\
\hline Total & - & - & - & - & - & - & - & - & - & - & - & - & 1891 \\
\hline
\end{tabular}

Source: Authors' original data

Number of respondents is given as $n$ 
TABLE 8: The influence of family relationships in the respondents' lives.

\begin{tabular}{lll}
\hline Variable & Frequency & $\%$ \\
\hline Description of Family in General. & & \\
Sweet and warm & 987 & 52.2 \\
Good & 645 & 34.1 \\
Fair & 146 & 7.7 \\
Not very good but tolerable & 64 & 3.4 \\
Intolerable and would like to leave & 21 & 1.1 \\
Do not know & 28 & 1.5 \\
Parental support for personal decisions. & & \\
Not at all & 83 & 4.4 \\
No & 102 & 5.4 \\
Yes & 1169 & 61.8 \\
Yes very much & 338 & 17.9 \\
Do not know & 199 & 10.5 \\
Having a good relationship with the brothers and sisters. & \\
All the time & 857 & 45.3 \\
Usually & 620 & 32.8 \\
Sometimes & 323 & 17.1 \\
Not usually & 61 & 3.2 \\
Never & 15 & 0.8 \\
Do not know & 15 & 0.8 \\
\hline Total & 1891 & 100 \\
\hline SOurce:Authors &
\end{tabular}

Source: Authors' original data

thematic areas for young people's preventive behaviour concerning HIV and AIDS are very strong in this student population.

In a study that was carried out in Sweden amongst the general population, sexual activity remains high amongst young people aged 16-25 years. ${ }^{32}$ High rates of sexual activity were expected in this study, as Lagos is perceived to be a cosmopolitan and sexually notorious city in Nigeria, even by Nigerians.

It is pertinent to note that adolescent African students remain more sexually active than their college colleagues. ${ }^{30}$

\section{Condom use}

Condom use is moderate amongst this study series (47.2\%). This is quite unusual as condom use is generally low amongst young people all over the world. ${ }^{35,32,4,38}$ In Nigeria, however, high condom use is more probable and driven by fear of pregnancy rather than any other reason because pregnancy in a female student generally signals the end of her formal education. The high level of use amongst study participants may be because of enhanced negotiation skills. ${ }^{36}$

\section{Self-efficacy}

Self-efficacy concerning the ability to engage in risky sexual behaviour was very high amongst study participants. Although this is a self-reported activity, this is commendable. Amongst Nigerian youths, there is a very high degree of self-confidence in almost everything they do. Whether this confidence is real or imagined is another matter entirely

This high level of self-efficacy pervades in the attitudes of college students on the African continent too. ${ }^{26}$ Studies consistently show that self-efficacy translates into safer sex practices generally. ${ }^{40,41}$ However, high self-efficacy does not always translate into safe sexual behaviour amongst college students. ${ }^{34}$

\section{Mass media influences (radio)}

One good development amongst young people is their love for music and the radio and other electronic media. The majority of the university students in this study listen to the radio every day and especially to Radio Unilag. Young people in Nigeria are fanatical football fans and the radio is the cheapest and fastest means of gathering news about their favourite teams, whether in Nigeria or in Europe. Exposure to mass media-related HIV and AIDS programming has been linked to attitudinal and behavioural changes both in Nigeria and in the rest of the world..$^{42}$ In a study conducted in China, exposure to multiple sources of HIV information (where at least one source was the mass media) was significantly related to HIV knowledge and a less stigmatizing attitude towards People Living With HIV and AIDS (PLWHA). ${ }^{42}$ Mass media in China has been a major source of HIV information to the public. ${ }^{42}$ Enhancing the content and penetration of HIV and AIDS campaigns within various channels of the media can be an important strategy in disseminating HIV knowledge and reducing HIV-related discrimination ${ }^{42}$ The possibility of reaching millions of young people through global networks with minimal marginal costs after production creates a new paradigm for reaching an important segment of young people. .33,4 $^{2}$

\section{Substance use and the perception of substance use}

Crack cocaine smoking has been identified as a risk factor for HIV and AIDS; $; 5,46,5$ however, as little as $20.8 \%$ of the students in the study group are suspected of taking hard drugs (Table 7) The substance most commonly abused by young people is tobacco, either as cigarettes or as snuff. ${ }^{49}$ This was also the case in this study, with rates being as high as $60 \%$. The risk, however, of contracting HIV and AIDS is more readily associated with hard drug use than with cigarette smoking. ${ }^{46,47,49}$ The other substance referred to in this study was alcohol. Increased sexual activity coupled with alcohol abuse increases the risk of contracting HIV and AIDS. ${ }^{50}$ Quite a high proportion of students in this study drank alcohol (approximately 64\%, Table 7). Further studies are needed to identify the drugs used by the $20.8 \%$ who were classified as hard drug users.

\section{Peer and partner pressure}

On average, the pressure exerted by these students on each other to perform adverse sexual acts was not high. There is no obvious explanation for this. This was in contrast to other studies on the continent where peer pressure amongst university students to have sex is high. ${ }^{20,51,50}$ The question is whether this lower peer pressure was a result of the high religiosity of these students. There is no doubt that previous HIV and AIDS programming in this student community has 
influenced the trend towards the high prevalence of these positive determinants.

\section{Family influence}

Family influences amongst the respondents of this study are very strong even for nonreproductive issues. Family ties in Nigeria remain very strong which may have influenced HIV and AIDS behaviour in this student population, although it was not explored in this study.

\section{Conclusion}

Programming for HIV and AIDS reduction on university campuses in Africa should be comprehensive rather than vertical single intervention based. In doing so, the five thematic areas of behaviour change communication amongst young people concerning reproductive health, backed by a health centre run by generalist doctors practicing Community Oriented Primary Care, are a sine qua non.

\section{Research significance}

Most programming and evaluation of interventions in sexual behavior amongst young people has been monothematic and population based. We present a multithematic programming that emanates from a family practice facility; an example of a partial process of Community Oriented Primary Care (COPC).

\section{Limitations of the study}

The usual reservation about the absolute reliability of selfreported observations in a research study is made. However the sheer number of respondents puts this reservation at the most minimum level.

\section{Acknowledgements}

We acknowledge the leadership support and kind gesture given to us to carry out this study by the then Vice-Chancellor of the University of Lagos, Prof Ibidapo-Obe who launched us on our journey into HIV and AIDS programming on campus by establishing the University of Lagos AIDS, Tuberculosis and Malaria (ATM) Committee. We also acknowledge the financial support given to us by the United States Embassy in Nigeria via the US President's Emergency Plan for AIDS Relief (PEPFAR) funds.

\section{Authors' contributions}

O.A. was the principal investigator and author of the study. He conceptualised the research work, conducted an extensive literature review, cleaned and analysed the initial data, wrote the first draft of the article and was responsible for the production of the final version. K.O. supervised data gathering, participated in the writing of the first draft of the article, participated in the critical review of the first draft of the article. A.M.O. coordinated field worker logistics in data gathering, collated questionnaire results, and participated in a critical review of the first draft of the article. VO participated in a critical review of the first draft of the article. AA participated in a critical review of the whole article. AA participated in a critical review of the whole article. KOA provided health center demographic data.

\section{References}

1. Garcia-Jardon M, Bhat VG, Blanco E, Stepian A. Post-mortem findings in HIV AIDS patients in a tertiary hospital in rural South Africa. Trop Doct. 2010; 40(2):81-84. doi:10.1258/td.2010.090465, PMid:20305099

2. Herlitz C. Sexual risk taking in the general population of Sweden(1989-2007). Sex Health. 2009; 6(4):272-280. doi:10.1071/SH08095, PMid:19917194

3. Hartell CG. HIV/AIDS in South Africa: a review of sexual behavior among adolescents. Adolescence. 2005;40(157):171-181. PMid:15861624

4. Magnani RJ, Seiber EE, Gutierrez EZ, Vereau D. Correlates of sexual activity and condom use among secondary school students in urban Peru. Stud Fam Plann.2001;32(1):53-66. doi:10.1111/j.1728-4465.2001.00053.x PMid:11326457

5. Monasch R, Mahy M. Young people: the centre of the HIV epidemic. World Health Organ Tech Rep ser.2006; 938:15-41. PMid:16921916

6. Blum RW, Nelson-Mmari K. The health of young people in a global context. J Adolesc Health. 2004:35(5):402-418. doi:10.1016/j.jadohealth.2003.10.007, doi:10.1016/S1054-139X(03)00537-8, PMid:15488435

7. Kelly MJ. Challenging the Challenger: Understanding and expanding the response of Universities in Africa to HIV/AIDS: A synthesis report for the Working group on Higher Education. Association for the Development of Education in Africa working group on Higher Education; 2001.

8. Caetano ME, Linhares IM, Pinotti JA, Maggio da Fonseca A, Wojitani MD, Giraldo PC. Sexual behavior and knowledge of sexually transmitted infections among university students in Sao Paulo. Brazil. Int J Gynaecol Obstet. 2010;110(1): 43-46. doi:10.1016/j.ijgo.2010.02.012, PMid:20695826

9. Buhi ER, Marhefka SL, Hoban MT. The State of the union: sexual health disparities in a national sample of US college students. J Am Coll Health. 2010;58(4):337346. doi:10.1080/07448480903501780, PMid:20159757

10. Teague SM. Perceptions of vulnerability to HIV/AIDS: a comparison of two college cohorts, 1990 and 2005. AIDS Educ Prev. 2009;21(6):526-537. doi:10.1521/aeap.2009.21.6.526, PMid:20030497

11. Caetano ME, Linhares IM, Pinotti JA, Maggio da Fonseca A, Wojitani MD, Giraldo PC. Sexual behavior and knowledge of sexually transmitted infections among university students in Sao Paulo, Brazil. Int J Gynaecol Obstet. 2010;110(1):43-46. doi:10.1016/j.ijgo.2010.02.012, PMid:206958

12. Alhikari R. Are Nepali students at risk of HIV? A cross-sectional study of condom use at first sexual intercourse among college students in Kathmandu. J Int AIDS Soc. 2010;13(1):7. doi:10.1186/1758-2652-13-7, PMid:20196856, PMCid:2847986

13. Buhi ER, Marhefka SL, Hoban MT. The State of the union: sexual health disparities in a national sample of US college students. J Am Coll Health. 2010; 58(4):337346. doi:10.1080/07448480903501780, PMid:20159757

14. Popa MI, Popa GL, Mihai A, Ocneanu M, Diaconu A.HIV and AIDS, among knowledge, responsibility and ignorance; a study on medical students at the end of their first university year. J Med Life. 2009; 2(3):308-312. PMid:20112476

15. Inungu J, Mumford V, Younis $M$, Langford S. HIV knowledge, attitudes and practices among college students in the United States. J Health Hum Serv Adm. 2009;32(3):259-277. PMid:20099580

16. Hou SI. HIV-related behaviors among black students attending Historically Black Colleges and Universities (HBCUs) versus white students attending a traditionally white institution (TWI). AIDS Care. 2009:21(8):1050-1057. doi:10.1080/09540120802626196, PMid:20024762

17. Adamchak S. E.; Bond K.; MacLaren L; Magnani R.J.; Nelson K; Seltzer J.R.; A guide to Monitoring and Evaluating Adolescent Reproductive Health Programs. Tool series 5. 2000; Focus on Young Adults.

18. Kirby D. The multiple antecedents of adolescent sexual risk-taking behavior, pregnancy and child bearing and their implications for research and programmes. (Draft paper prepared with support from the California Wellness Foundation): 1999.

19. Speizer I ;Mullen S; Literature Review on Adolescent Reproductive Health (Unpublished paper prepared for FOCUS on Young Adults, Washington D.C.); 1997.

20. Kabiru CW, Orpinas P.Factors associated with sexual activity among highschool students in Nairobi, Kenya. J Adolesc. 2009;32(4):1023-1039. doi:10.1016/j.adolescence.2008.08.001, PMid:18851878

21. Rhyme R, Bogue R, Kukulka G., Fulmar H. Community Oriented Primary Care: Health Care for the 21st Century. 1998; American Public Health Association.

22. Art B.,Deroo. I., De Maeseneer J. Towards Unity For Health: Utilising CommunityOriented Primary Care in Education and Practice. Education For Health [serial online]. 2000 [cited 2010 June 10];20(2):1-10. Available from http:www. educationforhealth.net/articles/defaultnews.asp

23. WM Castle. Measurement of socio-economic status in an urban African Community. Tropical Doctor. 1978;1:44-48. 
24. Pettifor AE, Levandowski BA, MacPhail C, Padian NS, Cohen MS, Rees HV. Keep them in School: the importance of education as a protective factor against HIV infection among young South African women. Int J Epidemiol. 2008;37(6): 126673. doi:10.1093/ije/dyn131, PMid:18614609, PMCid:2734068

25. Dodge B, Sandfort TG,Yarber WL, de Wit J. Sexual health among male college students in the United States and the Netherlands. Am J Health Behav. 2005;29(2):172-82. PMid:15698984

26. Gebreeyesus Hadera $H$, Boer $H$, Kuiper WA.Using the theory of planned behavior to understand the motivation to learn about HIV/AIDS prevention among adolescents in Tigray, Ethiopia. AIDS Care. 2007;19(7):895-900. doi:10.1080/09540120701203311, PMid:17712693

27. Lugoe WL, Klepp KI, Skutle A. Sexual debut and predictors of condom use among. secondary School students in Arusha, Tanzania. AIDS Care. 1996;8(4):443-52. doi:10.1080/09540129650125632, PMid:8863915

28. Herlitz C, Ramstedt K. Assessment of sexual behavior, sexual attitudes, and sexual risk in Sweden (1989-2003). Arch Sex Behav. 2005;34(2):219-229. doi:10.1007/s-10508-005-1799-5, PMid:15803255

29. Gerrard M, Gibbons FX, Bushman BJ. Relation between perceived vulnerability to HIV and precautionary sexual behavior. Psychol Bull. 1996;119(3):390-409. doi:10.1037/0033-2909.119.3.390, PMid:8668745

30. Epstein JA, Dusenbury L, Botvin GJ, Diaz T. Determinants of intentions of Junio High School students to become sexually active and use condoms: implications for reduction and prevention of AIDS risk. Psychol Rep. 1994;75(2):1043-1053. PMid:7862778

31. Anwar M, Sulaiman SA, Ahmadi K, Khan TM. Awareness of school students on sexually transmitted infections (STIS) and their sexual behavior: a cross-sectiona study conducted in Pulau Pinang. Malaysia BMC Public Health. 2010;10:47. doi:10.1186/1471-2458-10-47, PMid:20113511, PMCid:2824738

32. Herlitz CA, Forsberg M. Sexual behaviour and risk assessment in different age cohorts in the general population of Sweden (1989-2007). Scand J Public Health 2010;38(1):32-9. doi:10.1177/1403494809355072, PMid:19948649

33. Martinez-Donate AP, Hovell MF, Blumberg EJ, Zellner JA, Sipan CL, Shillington AM, Carrizosa C. Gender differences in condom-related behaviors and attitudes amon Mexican adolescents living on the U.S.-Mexico border. AIDS;16(2):172-186.

34. Mahoney CA. The role of cues, self-efficacy, level of worry, and high-risk behaviors in college student condom use. Sex Educ Ther. 1995;21(2):103-116.

35. Campbell SM, Peplau LA, Debro SC. Women, men, and condoms: attitudes 16(3):273-288. doi:10.1111/j.1471-6402.1992.tb00255.x, PMid:12286010

36. Jemmott JB 3rd, Heeren GA, Ngwane Z, Hewitt N, Jemmott LS, Shell R, O'leary A. Theory of planned behavior predictors of intention to use condoms among Xhosa adolescents in South Africa. AIDS Care. 2007;19(5):677-684. doi:10.1080/09540120601084308, PMid:17505930

37. Magnani RJ, Seiber EE, Gutierrez EZ, Vereau D. Correlates of sexual activity and condom use among secondary-school students in urban Peru. Stud Fam Plann. 2001;32(1):53-66. doi:10.1111/j.1728-4465.2001.00053.x, PMid:11326457

38. Beckman LJ, Harvey SM, Tiersky LA. Attitudes about condoms and condom use among college students. J Am Coll. Health. 1996;44(6):243-249. doi:10.1080/07448481.1996.9936851, PMid:8735161
39. Gagnon MP, Godin G. .The impact of new antiretroviral treatments on college students' intention to use a condom with a new sexual partner. AIDS Educ Prev. 2000;12(3):239-251. PMid:10926127

40. Mahoney CA, Thombs DL, Ford OJ. Health belief and self-efficacy models: their utility in explaining college student condom use. AIDS Educ Prev. 1995;7(1):32-49. PMid:7772455

41. Walter HJ, Vaughan RD, Ragin DF, Cohall AT, Kasen S. Prevalence and correlates of AIDS-related behavioral intentions among urban minority high school students. AIDS. 1994;6(4):339-350.

42. Li L, Rotheram-Borus MJ, Lu Y, Wu Z, Lin C, Guan J. Mass media and HIV/AIDS in China. J Health Commun. 2009;14(5):424-438. doi:10.1080/10810730903032994, PMid:19657923, PMCid:2743950

43. Geary CW, Burke HM, Castelnau L, Neupane S, Sall YB, Wong E.Exposure to MTV's global HIV prevention campaign in Kathmandu, Nepal; São Paulo, Brazil; and Dakar, Senegal. AIDS Educ Prev. 2007;19(1):36-50. doi:10.1521/aeap.2007.19.1.36, PMid:17411388

44. Lapinski MK, Nwulu P.Can a short film impact HIV-related risk and stigma perceptions? Results from an experiment in Abuja, Nigeria. Health Commun. 2008;23(5):403-412. doi:10.1080/10410230802342093, PMid:18850388

45. DeBeck K, Kerr T, Li K, Fischer B, Buxton J, Montaner J, Wood E.Smoking of crack cocaine as a risk factor for HIV infection among people who use injection drugs. Canadian Medical Association Journal. 2009;181(9):585-589. doi:10.1503/cmaj.082054, PMid:19841052, PMCid:2764753

46. Thanh DC, Hien NT, Tuan NA, Thang BD, Long NT, Fylkesnes K.HIV risk behaviours and determinants among people living with HIV/AIDS in Vietnam. AIDS Behav. 2009;13(6):1151-1159. doi:10.1007/s10461-008-9451-8, PMid:18787940

47. Liu Z, Lian Z, Zhao C.Drug use and HIV/AIDS in China. Drug Alcohol Rev. 2006; 25(2):173-175. doi:10.1080/09595230500538835, PMid:16627308

48. Christensen $M$. Information to young people about HIV/AIDS and drug abuse. A study of the knowledge and use of the information material in the youth center in Copenhagen. Ugeskrift for Laeger. 1998;160(38):5491-5495. PMid:9763922

49. Bansal RK.Sexual behaviour and substance use patterns amongst adolescent truck cleaners and risk of HIV/AIDS. Indian J Matern Child Health. 1992;3(4):108-110. PMid:12288387

50. Othero DM; Aduma P;Opil Co Knowledge, attitude and sexual practices of University students for advancing peer HIV education. East Afr Med. J. 2009;86 (1):11-15. PMid:19530543

51. Seloilwe ES. Factors that influence the spread of HIV AIDS among students of the University of Botswana. J.Assoc Nurses AIDs Care. 2005;16(3):3-10. doi:10.1016/j. jana.2005.03.003, PMid:16433112

52. Bagnall G, Plant MA.HIV/AIDS risks, alcohol and illicit drug use among young adults in areas of high and low rates of HIV infection. AIDS Care. 1991;3(4):355361. doi:10.1080/09540129108251591, PMid:1786267

53. Stulhofer A, Soh D, Jelaska N, Bacak V, Landripet I. Religiosity and Sexual Risk Behavior among Croatian College Students, 1998-2008. J Sex Res. 2010;10:1-12. doi:10.1080/00224499.2010.494257, PMid:20544469

54. National HIV sero-prevalence sentinel survey among women attending antenatal clinics in Nigeria. Technical Report. 2008; Federal Ministry of Health; National AIDS/STI Control Programme (NASCP). Abuja. 